MARTA ŠIMEČKOVÁ

Ústav pro jazyk český AV ČR

ORCID: 0000-0003-1210-8468

e-mail: simeckova@ujc.cas.cz

\title{
(DIS)KONTINUITA ČEŠTINY 16.-18. STOLETÍ NA PŘÍKLADU HLÁSKOSLOVÍ ${ }^{1}$
}

Loni uplynulo 400 let od bitvy na Bílé hoře, která se odehrála 8 . listopadu 1620 nedaleko Prahy a znamenala konec tzv. stavovského povstání, jehož se zúčastnily české stavy jakožto projev nevole proti habsburské nadvládě. Výsledek bitvy potvrdil jednak nárok Habsburků na český trůn, jednak vítězství radikálního katolicismu nad protestantstvím, jež bylo rozšířeno $\mathrm{v}$ části českých stavů. Tato událost měla dopad nejen na politicko-náboženské poměry $\mathrm{v}$ zemi, ale i na další oblasti s touto sférou více či méně související, mj. na dobovou literaturu a na setrvání češtiny v roli kulturního, prestižního jazyka. Rok 1620 představuje v českých dějinách natolik významný historický moment, že začal mj. plnit funkci opěrného bodu při periodizaci vývoje češtiny (detailně Kosek 2017); od daného data bývá zahajována etapa barokní neboli pobělohorské češtiny, jež se zvláště ve starších pracích dočkala záporného hodnocení coby čeština úpadková, charakteristická rozkolísaností a pronikáním mluvenostních, potažmo nářečních jevů do psané formy jazyka. Propojení barokní češtiny, zasazované zjednodušujícím způsobem povětšinou do let 1620-1775, s pokleslou úrovní se stalo mantrou, hojně šířenou i v pracích renomovaných odborníků na vývoj českého jazyka, jež dodnes setrvává v povědomí českého národa.

$\mathrm{V}$ následujícím textu se pokusím nastínit, jaké cesty vedly $\mathrm{k}$ vytvoření negativního obrazu češtiny 17. a 18. století, a to se zvláštním zřetelem na způsob argumentace podpořené konkrétními jazykovými nedostatky. Posléze bude pozornost upřena na skutečnou (nikoliv předpokládanou či tušenou) jazykovou praxi 16.-18. století, konkrétně na projevy čtyř jevů z roviny hláskosloví, jimž jsem se podrobně věnovala

1 Tento př́íspěvek vznikl na základě řešení projektu č. DG20P02OVV029 Nářeči českého jazyka interaktivně. Dokumentace a zpřistupněni mizejícího jazykového dědictví jako nedilné součásti regionálních identit; poskytovatel podpory Ministerstvo kultury, Program NAKI II. Práce používá mj. data, která poskytuje výzkumná infrastruktura LINDAT/CLARIAH-CZ (https://lindat.cz) podporovaná Ministerstvem školství, mládeže a tělovýchovy České republiky (projekt č. LM2018101). 
již ve své disertační práci (Šimečková 2016a). Těmito jevy je protetické v- (napřr. okno $>$ vokno), náslovná diftongizace $u ́$ - > ou- $(\dot{u} l>o u l)$, diftongizace $y$ (popř. $i)>e j$ (starý mlýn > starej mlejn, zítra > zejtra) a úžení é > $i$ (v grafice též ý; dobré mléko > dobrý mliko). Jazyková data, jež byla získána excerpcí více než stovky tisků z 16.-18. století, podala ve jmenované práci svědectví o někdejší jazykové uzanci panující v tiskařské produkci domácí provenience, taktéž v ní byly stanoveny základní faktory pro (ne)užití konkrétní hláskové podoby slova či slovního tvaru². Na sebraný materiál lze ovšem nahlížet z různých perspektiv - a jednou z nich je otázka (dis)kontinuity češtiny, nebo spíše češtin, ve stanoveném časovém úseku tří staletí.

$$
* * *
$$

Než předejdu k prvnímu vytyčenému úkolu, pokládám za potřebné připomenout důležitá fakta, jež mají na první pohled jen nepřímý vliv na vývoj jazyka, avšak při bližším ohledání budou právě ona nápomocna pro vytvoření plastičtějšího obrazu zasazeného do kulis dotčeného období. Zatímco 16. století znamenalo pro české země rozmach literární produkce ve většině tehdy pěstovaných žánrech a literárních oblastech, 17. století přineslo zpomalení knihtisku. Literatura sloužila jako nástroj protireformačního programu, důsledkem čehož se zúžil okruh vydávaných texti̊ hlavně na náboženskou literaturu (např. homiletika, kancionály, čtení o poutních místech a zázracích), v menší míře byla vydávána i díla historiografická (kroniky) a prakticky odborné prŕručky (kuchařské knihy, kalendáře, hospodářské pranostiky). Mnoho textů vzniká kompilací starších předloh nebo translací z cizích jazyků, jen málokteré vybočují uměleckým zpracováním nebo původností ${ }^{3}$. Důvodem útlumu některých žánrů rozvíjených dříve $\mathrm{v}$ češtině byl též odliv vzdělanců $\mathrm{z}$ řad evangelíků do exilu, mezi nimiž byli jak tvưrci knižní produkce (nakladatelé, tiskaři, spisovatelé), tak jejich odběratelé.

Majetek exulantů skupovali cizinci, převážně německy mluvící; i z toho důvodu klesla poptávka po českých knihách. Sílící vliv cizinců však lze zaregistrovat už v době před r. 1620. Původně německá menšina byla tvořena zámožnými obyvateli z rrad šlechty, měšt’anstva a vzdělanstva, kteří se těšili podpoře u císařského dvora,

\footnotetext{
${ }^{2}$ Pro stanovení uzance humanistické češtiny byla využita též data z monografie J. Poráka Humanistická čeština. Hláskosloví a pravopis (1983), jež vyniká detailním popisem vybraných hláskových pochodů (též dobové grafiky) a zohledněním kvantitativní analýzy v podobě podrobných tabulek. Bylo též přihlédnuto $\mathrm{k}$ mnoha dalším, drobnějším pracím. Viz též pozn. 7.

${ }^{3} \mathrm{Z}$ čestných výjimek jmenujme např. báseň Co Bůh? Člověk?, na jejíž bezesporné hodnoty jako první upozornil J. Vašica (1934), nebo Svatováclavskou bibli, která se stala literární a jazykovou autoritou pro barokní období (obdobně jako dřive Kralická bible, jejíž kvality se odrazily mj. na oficiálním katolickém biblickém překladu). Některé kvalitnější texty byly zveřejněny též ve výborech barokní literatury, o něž se zasloužili např. Z. Kalista, M. Kopecký, M. Sládek nebo Z. Tichá. Kritické zhodnocení barokní literatury dosud schází, a to jednak z důvodu předsudků o její úpadkovosti, zobecněných již v 19. století (viz výklad níže), jednak kvůli zpolitizování tématu českého baroka během komunistické éry (viz třeba Válka 1968). Přes jisté nejistoty v hodnocení barokní literatury z hlediska její (ne)uměleckosti je zjevné, že některé typy česky psaných tisků se v 17. století a ve velké části století následujícího vytrácí, jak lze soudit ze soupisů literárních památek uvedených např. v Knihopisu.
} 
také se rozrůstala přílivem německých řemeslníků do českých měst. V roce 1615 byl kvůli stížnostem na neznalost češtiny u přistěhovalců stanoven artikul $O$ zachování starožitného jazyka českého a vzdělání jeho, jenž měl přimět jinojazyčné obyvatelstvo osvojit si češtinu. Nařízení však nebylo v praxi aplikováno; jeho vydání nadto poukazuje na skutečnost, že se jazyková situace posouvala $v$ neprospěch češtiny již před r. 1620.

Po bitvě na Bílé hoře byly povoleny výhradně katolické tiskárny (významné postavení měla např. Akademická impresí u sv. Klimenta blíž mostu), zatímco dílny, jež byly dř́ve v rukou nekatolíků, byly konfiskovány (mezi nimi mj. ta, kterou vedl Samuel Adam z Veleslavína, syn někdejšího architypografa Daniela Adama z Veleslavína, jenž byl evangelíkem a př́ivržencem Fridricha Falckého; podrobně viz Voit 2006). Roku 1621 bylo vydáno první cenzurní nařízení, po němž následovala další, jež omezila do té doby slibný vývoj na poli literárním. Starší tisky nevyhovující radikálnímu katolicismu byly páleny jakožto kacířské s podporou o různé rejstř́íky (např. Index Bohemicorum librorum prohibitorum nebo Koniášovy Klíče), perzekuováni byli rovněž jejich držitelé.

To mělo samozřejmě dopad na sféry působnosti češtiny. Byly v ní zpravidla produkovány texty nižšího stylu, jež byly určeny pro čtenáře méně vzdělané, obzvláště venkovského původu, zatímco v odborné a vysoce umělecké tvorbě dominovala latina a němčina. Roku 1627 byla vedle češtiny zavedena právě němčina jako jazyk úřední, čímž byl posílen společenský status tohoto germánského jazyka, jenž se stále progresivněji prosazoval jak ve společenských vrstvách nejvyšších, tak i u obyvatel měst. Již roku 1690 byly celé soudní procesy vedeny v němčině, česká zůstala uchována pouze úvodní formule. Čeština byla postupně vyloučena též z úřadů a vyšších škol.

\section{$* * *$}

Vzhledem k naznačenému dějinnému vývoji se na pobělohorskou éru nahlíželo dogmatem rozkladu a úpadku, jenž se měl dotýkat tehdejších poměrů politických, náboženských, kulturních, hospodářských, též literárních a jazykových. V oblasti literatury stál na počátku později ustrnulé teze J. Dobrovský, jenž označil etapu mezi léty 1520-1620 za „věk krásný neb zlatý““ („das schöne oder goldene Zeitalter der böhmischen Sprache“, 1792: 171), zatímco rokem 1620 podle něj ,začíná nejsmutnější doba české řeči a literatury“ (,hier fängt nun die traurigste Epoche der böhmischen Sprache und Litteratur“، ibid., s. 193). Dobrovský položil základy periodizace českých literárních dějin, patrně neúmyslně též vývoje češtiny; ve své práci se zaměřil téměř výhradně na deskripci literárních děl, jež se jen místy opírá o proměny společenské, nikoliv jazykové (viz též Stich 1991: 57). Autorita Dobrovského byla posvěcena převzetím jím navržené šestifázové periodizace J. Jungmannem, pro nějž rokem 1620 „počíná se smutná doba jazyka a literatury české“ (1825: 338), kdy domácí jazyk „V potupu vešel“" (ibid.). Jungmann oproti svému vzoru konkretizoval některé jazykové nedostatky jím kritizovaného období (ibid., 342-343).

V obdobném duchu se nesou mladší práce věnované literárnímu a/nebo jazykovému vývoji. V nich je období humanismu vzletně nazýváno jako éra „vrcholného 
rozkvětu“ (takto např. Weingart 1918: 23), zatímco v následujících dvou staletích se „,nad českým lánem rozestíralo temno“ (ibid., 31), zbyl tu jen „kal a rum“ (Flajšhans 1924: 312), kdy český jazyk „hyne a upadá“ (ibid., 302) a jeho jazyková úroveň je „nevalná“ (Hausenblas 1958: 77). Obdobná tvrzení lze dohledat i v práci Havránkově - v pobělohorském období prý nelze „mluvit o dalším vývoji spisovné češtiny, nýbrž o jejím ústupu“ (Havránek 1980: 71), obdobně v novějších pracích, podle nichž byl prý vývoj kulturní češtiny bud' zcela ,,podlomen“ (Šlosar a kol. 2009: 91), nebo u ní došlo minimálně k ,,poklesu úrovně“ (Komárek 2012: 34). Vytýkána je rozkolísanost (s odkazem na dříve jednotnou normu, takto např. Šlosar a kol. 2009: 93) a přerušení vývoje (napřr. Flajšhans 1924: 306). Všechny práce spojuje odmítavý postoj k období po roce 1620. O tomto milníku píše V. Flajšhans: „Železné kostky Osudu, jež na Bílé hoře 8 . listopadu 1620 padly proti národu českému, zadržely na 150 let všechnu práci na poli jazyka českého i jeho písemnictví“ (1924: 292).

Odhlédneme-li od mnohdy citově zabarvených, metaforami nabitých popisů, lze si povšimnout malého počtu jazykových dokladů, o něž by byly tyto negativní soudy podepřeny. Pokud jsou nějaké jevy jmenovány, tak jen na obecné bázi, bez citace konkrétního zdroje, popř. bez zmínky o provedeném jazykovém rozboru, nebo alespoň sondě. $Z$ malých útržků lze sestavit následující výčet znaků pobělohorské češtiny, jež jsou častěji zmiňovány v daných pracích o jazykovém vývoji: 1) jazyk po r. 1620 prý inklinuje $\mathrm{k}$ hovorovosti, tj. k mluvenostním a nářečním prvkům, 2) též k prvkům umělým, tj. k neologismům a slovům cizího původu, porůznu komoleným. Z konkrétních hláskových projevů to je: pronikání protetického $v$-, náslovná diftongizace $u$ - > ou-, úžení é $>i$ a diftongizace ý (popř. $i$ ) $>e j$. Z jevů tvaroslovných: nestandardní skloňování substantiv (rukmi namísto rukama/rukami) ${ }^{4}$, silný tlak původně duálových koncovek v instrumentálu plurálu (s pánoma, branama n. s pány, branami), stírání rodových rozdílů u adjektiv (tvar dobrý pro všechny rody n. dobrý, dobrá, dobré), chybné tvary zájmen (tech, tem n. těch, těm) ${ }^{5}$ a číslovek (tři stě n. tři sta), užívání složených tvarů u posesivních adjektiv (Adamový rod n. Adamův rod), kolísání kvantity, nekongruentní přechodníky, unifikace koncovek 3. osoby plurálu prézentu u sloves 4. trrídy (sází n. sázeji), chybně utvořené komparativy adverbií (draze, dražeji n. dráže, dráž) aj.

Je otázkou, nakolik se tyto jevy - v mluveném jazyce dozajista živé - reflektovaly do jazyka psaného a nakolik byly v rámci dobové uzance nepatřičné? Dřívější badatelé totiž neusilovali o poznání vývoje jazyka sui generis, ale přenášeli tento vývoj do interpretačního rámce tvořeného vnějšími nebo literárními dějinami. Samotný jazyk stál vně - byl chápán jako nástroj národní identity, do popředí se tak dostával jeho proměnlivý funkční rádius a vztah ke konkurenčním jazykům. Jeho kvality byly hodnoceny podle normy novodobé spisovné češtiny, jakékoliv odchylky byly

\footnotetext{
${ }^{4}$ Vypuštění samohlásky - $a$ - má patrně náreční původ, srov. tvar kravma s výrazným areálem v severovýchodních Čechách, jenž byl zaznamenán v materiálu z 80. let minulého století. Viz Český jazykový atlas 4, 2002: 289-290.

${ }^{5}$ Těch je tvar gen. pl. ukazovacího zájmena ten, ta, to; těm je tvar dat. pl. V nářečích vedle nich koexistovaly hláskově různorodé varianty, např. ještě v 80 . letech 20 . století bylo pro tvar těch evidováno několik nářečních obměn, např. tech, tich, tych, tejch. Viz Český jazykový atlas 4, 2002: 386-388.
} 
tudíž označeny za př́iznaky tzv. rozkolísanosti. Konfrontace jazykové uzance 17. a 18. století s moderní češtinou je však neadekvátní; jazyk neustrnul, ale dál se vyvíjel, byt' jiným směrem, než by si přáli zastánci zmíněného ahistorického přístupu. Jednak se živě rozvíjel jazyk mluvený, o němž toho bohužel př́iliš nevíme, jednak jazyk psaný, jenž byl sice v pobělohorském období omezen na texty určitých žánrů, avšak i zde nacházíme bohatství materiálu pro výzkum jazyka tisků a rukopisů. Jak tento jazyk vypadal? Co bylo pro pobělohorské texty společné, a co naopak periferní? Co lze označit za rysy kulturní češtiny, a co naopak za projevy individuální, mluvenostní, dialektické? To by mělo být náplní tzv. dějin českého jazyka, které by se oproti starším „vývojům“ - měly oprostit od sledování linie vedoucí k novodobé spisovné češtině a od soudů třídících jazykové jevy na bílé a černé, vhodné a nevhodné apod. Na rozdílné chápání vývoje a dějin jazyka upozornil O. Koupil (2007) v recenzi monografie J. Marvana Cesty $k$ dějinám češtiny, kterou doplnil o úvahu nad těmito dvěma rozdílnými pojetími. Než však bude moci česká diachronní jazykovědná bohemistika přistoupit $\mathrm{k}$ tvorbě nových dějin, bude nutné důkladně prozkoumat jednotlivé jazykové jevy, stanovit způsob jejich šíření v textech, frekvenci a př́ípadné činitele ovlivňující jejich (ne)uplatnění.

\section{$* * *$}

Zpočátku je nutno postupovat malými krůčky ${ }^{6}$. Jedním z nich je zevrubný výzkum hláskosloví. Na tomto poli jsem se pokusila přispět analýzou čtyř výše zmíněných

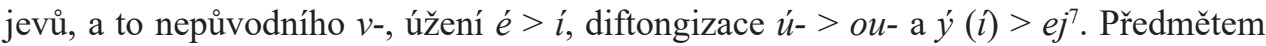
mého zájmu se stal jazyk tisků náboženských, historiografických a prakticky odborných, níže uvedené závěry jsou tudíž poplatné pouze pro jazyk tohoto typu komunikátů. Metodologicky jsem postupovala v souladu s J. Porákem (1983), jenž obdobnému rozboru podrobil humanistické texty, výběrově též některé ze začátku 17. století. Díky uplatnění týchž postupů byla umožněna komparace zjištěných dat, jež vedla jednak k potvrzení některých starších tvrzení, též k jejich zpřesnění

\footnotetext{
${ }^{6}$ Některé kroky již byly učiněny. Výběrově lze jmenovat např. monografii Vývoj přechodníkových konstrukcí ve staré češtině (Dvořák 1970), zahrnující mj. jazykový materiál ze 17. století. Jedno syntaktické téma podrobně zpracoval P. Kosek v knize Spojovací prostředky v češtině období baroka (2003). Lexiku se věnoval A. Kamiš v monografii Slovní zásoba české publicistiky 18. století (1974); z jeho rozboru zřetelně vysvítá kontinuita se starším vývojem, byt' sám autor neopouští staré schéma spojené s představou o úpadkovosti jazyka (s. 7). K dispozici je i řada studí, časopiseckých a sborníkových.

${ }^{7}$ Nejde samozřejmě o první práci zabývající se hláskoslovím, respektive těmito čtyřmi hlásk. jevy. Pro češtinu máme $\mathrm{k}$ dispozici řadu renomovaných historických mluvnic a popisů (např. od J. Gebauera, F. Trávníčka, A. Lamprechta), avšak vzhledem k jimi sledovaným cílům je v nich uvedený výklad do jisté míry zjednodušený, nebot' bylo zapotřebí věnovat prostor i dalším jazykovým pochodům. Období 17. a 18. století se v nich nadto dočkalo jen malé pozornosti, např. Gebauer ve své mluvnici barokní období „takřka zcela ignoruje“ (Kosek 2003: 9). Další cennou publikací pro výzkum češtiny 17. a 18. století je např. monografie M. Janečkové (2009), v níž je zpracován bohatý jazykový materiál, bohužel však bez kvantitativního wyhodnocení. K dispozici je i řada dílčích studií, př́ípadné zájemce o danou problematiku odkazuji na soupis literatury ve své disertační práci. K nim lze připojit některé novější práce, např. podrobnou studii o protetickém v- ve smolných knihách (Dittmann 2019).
} 
a zejména možnosti vyjádřit se $\mathrm{k}$ dalším osudům sledovaných jevů až do počátku národního obrození (s oporou o vybrané jazykově reflexivní texty i v navazujícím období).

Z chronologického hlediska byl srovnáván jazyk tisků humanistických, barokních a raně obrozeneckých. U některých jevů byl zjištěn poměrně vyrovnaný stav, nebo alespoň postupně se ustalující, u jiných bylo shledáno variování bez ohledu na dobu vzniku textů. Mezi relativně stabilní jevy lze zařadit protetické v-. Nejčastěji bylo doloženo $\mathrm{v}$ tiscích $\mathrm{z}$ 16. století (podle Poráka zejména $\mathrm{v}$ pražských tiscích z 30.-50. let [1983: 127]), a to především v textech prakticky odborných, mezi nimiž v tomto ohledu vynikaly početnice (viz Šimečková 2013). Nebylo výjimkou, že v jenom textu bylo totéž slovo tištěno s protezí i bez ní. Již ve 2. polovině 16 . století a v 17. století docházelo k oslabení nepůvodní hlásky, jež byla postupně spojována jen s jistým okruhem slov, např. vohlav, vorati, votava. U těchto výrazů se protetická hláska natolik vžila, že začala být mylně interpretována jako jejich pevná, náležitá složka. Na její nepůvodnost bylo upozorňováno teprve v průběhu 19. století v př́ručkách o češtině, a tak byla i u těchto výrazů odstraněna. Z uvedeného plyne, že období 16. století lze pokládat za prípravnou fázi, během níž do textů pronikaly jevy dozajista rozšířené v mluvené češtině (přinejmenším v oblasti středních Čech, viz Utěšený 1955, též Šimečková 2016b), zatímco po r. 1620 je proteze vědomě eliminována, jak svědčí data zachycená v tabulce 1 .

Tabulka 1. Průměrné zastoupení protetického $v$ - $^{8}$

\begin{tabular}{|c|c|c|}
\hline & jen $v o-$, popř. kolísání vo-/o- $(\%)$ & jen $o-(\%)$ \\
\hline $1500-1620$ & 33 & 67 \\
\hline $1620-1775$ & 4 & 96 \\
\hline $1775-1800$ & 1 & 99 \\
\hline
\end{tabular}

Ústup protetické hlásky z jazyka tisků ilustruje graf $1, \mathrm{v}$ němž je znázorněn průměrný výskyt slov použitých $\mathrm{v}$ analyzovaných tiscích výhradně bez protetické hlásky ${ }^{9}$. Všimněme si, že přes prvotní výkyvy v tiscích ze 16. století mají již texty 17. a 18. století poměrně vyrovnané zastoupení slov bez proteze, neshledáváme tu výraznější př́klon k protetizovaným podobám oproti praxi před rokem 1620.

\footnotetext{
${ }^{8}$ Procentuální zastoupení bylo zjišt’ováno pomocí výpočtu podle průměrného zastoupení hyperlemmat. Ke statistickému šetření viz Šimečková 2016a: 24-26.

${ }^{9}$ Pro tvorbu grafu byla využita data ze všech tisků, vzhledem $\mathrm{k}$ jejich počtu se do vodorovné osy promítly letopočty jen některých $\mathrm{z}$ nich. $\mathrm{U}$ tisků $\mathrm{s}$ týmž datem bylo přistoupeno $\mathrm{k}$ výpočtu průměrné hodnoty klasickým způsobem.
} 


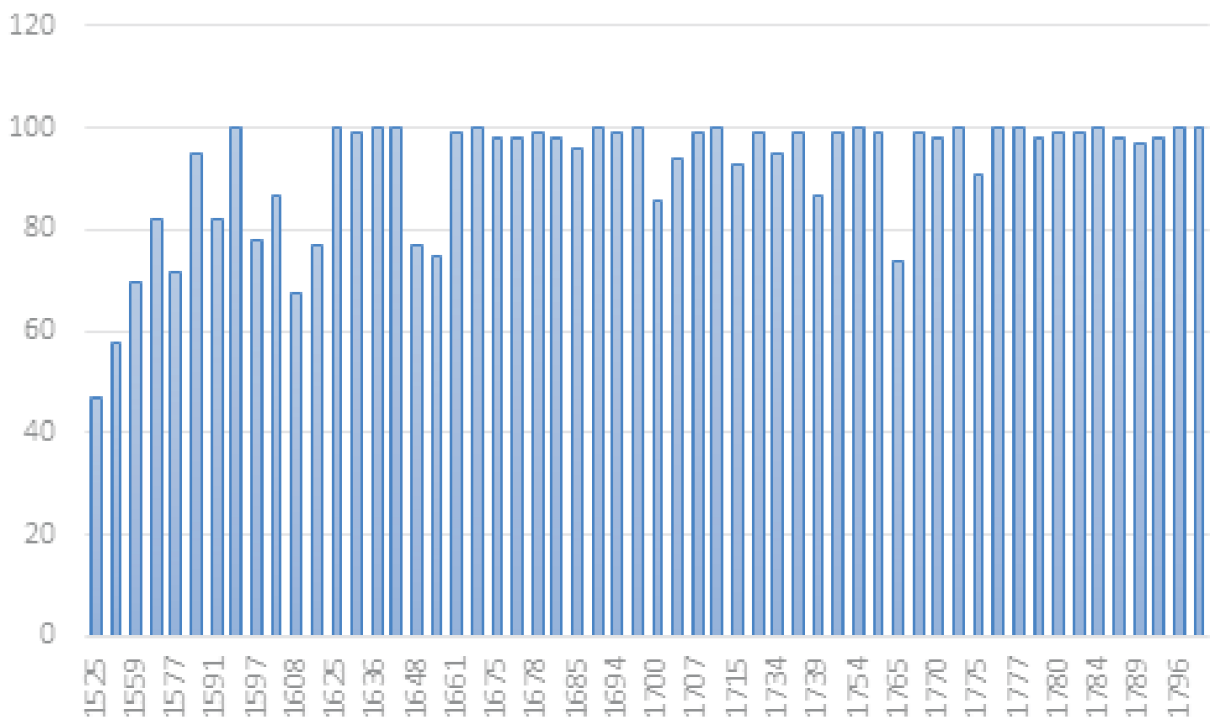

Graf 1. Průměrné zastoupení slov tištěných výhradně bez proteze

Ještě zřetelnější linii lineárního vývoje (nikoliv diskontinuity) lze sledovat u některých projevů diftongizace $\boldsymbol{y}(\boldsymbol{i})>\boldsymbol{e j}$, a to směrem k potlačení výsledku změny, konkrétně u formací utvořených príponou -ýr (např. arkýř, měchýr) a u původního $i$ (cín, sito, vozik). Totéž platí pro koncovky tvrdé složené deklinace, které během 17. a 18. století odrážely novější ej minimálně; pokud byla dvojhláska v některém tisku nalezena, pak šlo o ojedinělý doklad, v porovnání s množstvím nediftongizovaných př́padů statisticky nedůležitý. Totéž lze vztáhnout na výsledky úžení $\boldsymbol{e}>\boldsymbol{i}$ v některých pozicích - např. u substantiv typu obili (pův. obilé) se zcela prosadila zúžená forma již v tiscích ze 16. století, stejně tak u tvarů 4. slovesné trrídy typu oni chválí (namísto chválé) a u participií typu chválíc, chválíce (pův. chváléc, chváléce). Novější $i$ bylo podporováno dále u odvozenin se zakončením -ér (nověji -iřr, v grafice též -ýr r, např. centnýr sufixem (např. kamínek, mnohdy však vedle kamének). Jinak je tomu ve vnitřních pozicích, pro něž u obou jevů panuje nevyrovnanost, jak svědčí tabulky 2 a 3.

Tabulka 2. Průměrné zastoupení diftongu $e j(<y)$ ve vnitřní pozici

\begin{tabular}{|c|c|c|c|}
\hline & jen $e j(\%)$ & kolísání $e j / \hat{y}(\%)$ & jen $\dot{y}(\%)$ \\
\hline $1500-1620$ & 35 & 20 & 45 \\
\hline $1620-1775$ & 44 & 18 & 38 \\
\hline $1775-1800$ & 45 & 16 & 39 \\
\hline
\end{tabular}

$\mathrm{Z}$ nich je patrné, že po celé sledované období nedošlo $\mathrm{k}$ fixaci jedné z podob (diftongizované, či nediftongizované; zúžené, či nezúžené), k tomu prrispěly až snahy o kodifikaci spisovné češtiny v 19. století (viz Šimečková 2016a: 247). Přesto lze 
postihnout určitá slova tíhnoucí ke konkrétní podobě, a to bud' k novější (napřr. hejbati, pejcha, vejš; chlív, kolíbka, líhati), nebo k původní (např. výborný, výsost; déšt', chléb, péče). Některé jednotliviny se vyvíjely specifickým způsobem, nap̌r. adverbia typu poprvé, zadruhé nebo lép, méň (z pův. lépe, méně) byla progresivním změnám otevřenější; u některých výrazů sehrály roli další faktory, např. jejich původ, sémantika nebo kolísající kvantita vnitřního vokálu. Co je však evidentní, je obdobné rozložení ne/diftongizovaných a ne/zúžených variant v tiscích ze všech tří údobí, kdy opět nelze hovořit o výraznějším nárůstu slov s ej nebo $i(<e ́)$ po roce 1620.

Tabulka 3. Průměrné zastoupení $i(<e ́)$ ve vnitřní pozici

\begin{tabular}{|c|c|c|c|}
\hline & jen $i(\%)$ & kolísání $i / e ́ e(\%)$ & jen $\dot{e}(\%)$ \\
\hline $1500-1620$ & 16 & 14 & 70 \\
\hline $1620-1775$ & 24 & 8 & 68 \\
\hline $1775-1800$ & 24 & 11 & 65 \\
\hline
\end{tabular}

Ve srovnání s probranými jevy by se mohlo zdát, že alespoň v př́padě náslovné diftongizace $u$ - > ou- došlo v pobělohorském období k uvolnění jazykové normy projevující se př́íklonem k dvojhlásce (viz tabulka 4). Ta byla podle J. Poráka (1983: 109) na vzestupu už od 30. let 16. století, v mladších textech byla již silně zakořeněna $\mathrm{u}$ většiny výrazů $\mathrm{s}$ dřívějším náslovným $u$-. Nárůst slov $\mathrm{s} o u-\mathrm{v}$ tiscích 17. a 18. století nelze podle mého názoru vysvětlovat jako odraz jazykového úpadku, ale jako výsledek plynulého vývoje.

Tabulka 4. Průměrné zastoupení ou- $(<\dot{u}-)$

\begin{tabular}{|c|c|c|c|}
\hline & jen ou- $(\%)$ & kolísání ou-/ú- $(\%)$ & jen $\dot{u}$ - $(\%)$ \\
\hline $1500-1620$ & 40 & 20 & 40 \\
\hline $1620-1775$ & 73 & 8 & 19 \\
\hline $1775-1800$ & 71 & 5 & 24 \\
\hline
\end{tabular}

Podrobnější data poskytuje graf 2, v němž jednotlivé sloupce značí průměrný výskyt slov (hyperlemmat) tištěných $\mathrm{v}$ jednotlivých literárních zdrojích výhradně s náslovným ou-, popř. evidovaných dubletně. Zaujmou především proměnlivé hodnoty v levé polovině grafu, reflektující stav 16. a začátku 17. století. Oproti tomu v novějších textech jsou hodnoty částečně vyrovnány; případné odchylky jsou dány zastoupením slov s kolísající kvantitou (popr. absencí vokalické délky, odlišné od dnešního stavu), nap̌r. úhel, úsilí, úsvit (dříve snad uhel, usilí, usvit/usvít). Souvisí rovněž se stylovou diferenciací textů a místem jejich vzniku, nap̌r. texty s náboženskou tematikou, obzvlášt’ spojené s kralickou tiskárnou, dvojhlásku přijaly jen v omezené míře (viz číselné údaje uvedené Porákem [1983: 111, 112]). Z toho důvodu nebyly kralické tisky do grafů zahrnuty. 


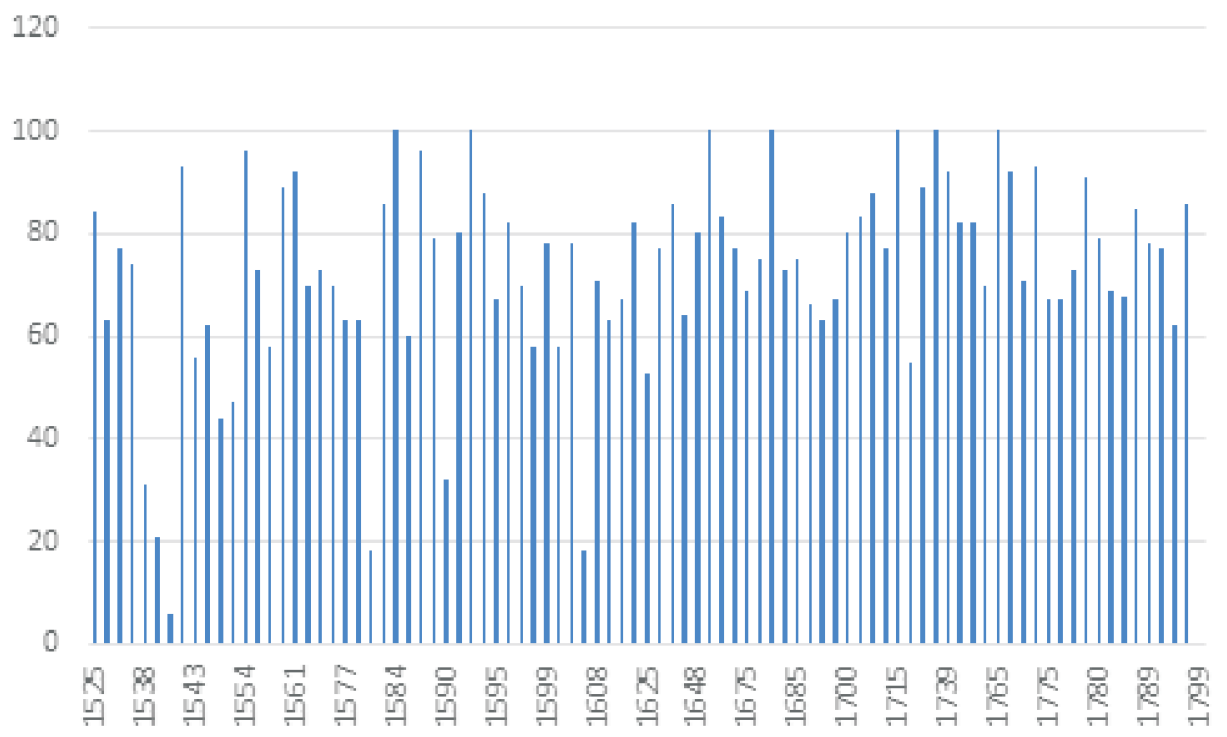

Graf 2. Průměrné zastoupení slov tištěných s náslovným ou- (výhradně nebo dubletně)

$* * *$

Analytická část představuje dílčí výřez mého výzkumu, zde záměrně zjednodušený a zhuštěný, nebot' cílem tohoto příspěvku nebylo popsat sledované jevy do hloubky, ale usouvztažnit některé jejich aspekty s otázkou (ne)lineárního vývoje a zejména ošidného středobodu, jímž se stal pro některé starší badatele na poli vývoje češtiny právě rok 1620. Je zřejmé, že se jazyk tisků i po tomto datu nadále vyvíjel a že tu existovaly snahy o jeho sjednocení. Řada jevů, u nichž byla ještě na konci 16. století typická dubletnost, se stabilizovala, a to jednak návratem ke staršímu stavu (výrazné je to u koncovek tvrdé složené deklinace, v nichž se nové ej, $i$ v 17. ani 18. století téměř neprosadilo; dále pozdější odmítnutí protetického $v$-s výjimkou výrazů, u nichž došlo k jeho ustálení), jednak př́klonem k provedení změny (náslovné ou-). Některé jevy se staly více či méně pevnou složkou jazyka tisků, nelze je tudíž hodnotit prizmatem současné spisovné češtiny, do níž např. náslovné ou- nepřešlo. Stejně tak není vhodné chápat jako dialektické či „,nespisovné“ ty prvky, které byly otevřeny variantnosti - kolísání hláskové (nebo spíše hláskově-pravopisné) podoby některých slov s vnitřním ý/ej a é/í bylo pro češtinu části 16., též 17. a 18. století typické, zvláště u některých slov (např. mýdlo/mejdlo, stéblo/stýblo). Míra tohoto kolísání byla dána jednak slovní zásobou, která byla v konkrétním tisku užita (u některých lexémů byla stanovena inklinace k přijetí, nebo naopak odmítnutí nové střídnice), jednak literárním žánrem. Nové střídnice se přitom prosadily i v autoritativních tiscích, pro pobělohorské období např. ve Svatováclavské bibli (Vintr 1992: 200), byt' v menší míře než v tzv. nižší literatuře. 
Přestože dějinný vývoj po roce 1620 znamenal pro české země řadu výrazných změn v politicko-společenském uspořádání, náboženství, kultuře či literatuře, na rozvoj češtiny měl dopad jen částečný. Bezesporu zásadní změnou byla ztráta výsadního postavení češtiny coby jazyka státního a úředního, které převzala němčina, též zúžení pole její působnosti v různorodosti v ní pěstovaných literárních žánrů. Ovšem jazyk tisků, podrobený pečlivému rozboru, nepodává žádné svědectví o „úpadku“, „,poklesu úrovně“, či dokonce „přerušení vývoje“, alespoň ne v př́ípadě oněch čtyř hláskových jevů, na něž bylo ve starších pracích nejvíce upozorňováno jako na indikátory jazykového rozkladu. K těmto negativním soudům se dospělo mj. $\mathrm{z}$ důvodu nepochopení jazyka 17. a 18. století, jeho vlastních pravidel, jež byla odlišná od těch novočeských, dříve vnímaných jako srovnávací báze, přičemž jakýkoliv odklon od ní byl vyhodnocen jako chyba. Pojd'me psát dějiny češtiny, bez dogmat a ideologií. Poznejme češtinu takovou, jaká opravdu byla, a popišme, jak fungovala v různých typech textů, tištěných i rukopisných. Cesta je to nesnadná, avšak jedině takto se dobereme kýženého cíle - poznání.

\section{Literatura}

Český jazykový atlas 4, 2002, Praha. K dispozici je též elektronická verze: https://cja.ujc.cas. cz/e-cja/.

Dittmann R., 2019, Protetické v ve Smolné knize velkobítešské (1556-1636), „Listy filologické” 142 , s. $369-406$.

Dobrovský J., 1792, Geschichte der Böhmischen Sprache und Litteratur, Praha.

Dvořák E., 1970, Vývoj prechodnikových konstrukci ve starši češtině, Praha.

Flajšhans V., 1924, Náš jazyk mateřský, Praha.

Hausenblas K., 1958, Vývoj predmětového genitivu v češtině, Praha.

Havránek B., 1979, Vývoj spisovného českého jazyka, Praha.

Janečková M., 2009, K jazyku českého baroka, Praha.

Jungmann J., 1825, Historie literatury české aneb soustavný přehled spisů českých, s krátkou historii národu, osvíceni a jazyka, Praha.

Kamiš A., 1974, Slovní zásoba české publicistiky 18. století, Praha.

Komárek M., 2012, Dějiny českého jazyka, Brno.

Kosek P., 2017, Periodizace vývoje češtiny, in: CzechEncy - Nový encyklopedický slovník češtiny, eds. P. Karlík, M. Nekula, J. Pleskalová, Brno, online: <https://www.czechency.org/>.

Kosek P., 2003, Spojovaci prostredky v češtině obdobi baroka, Brno.

Koupil O., 2007, Cesty k dějinám češtiny, „Listy filologické” 130, s. 144-147.

Porák J., 1983, Humanistická čeština. Hláskosloví a pravopis, Praha.

Stich A., 1991, O počátcích moderni spisovné češtiny, „Naše řeč” 74, s. 57-62.

Šimečková M., 2016a, Hláskosloví v češtině 16.-18. století, Brno. [Nepublikovaná disertační práce.]

Šimečková M., 2016b, Př́spěvek $k$ historickému vývoji protetického v- u českých oikonym, „Acta onomastica” 55, s. 290-296.

Šimečková M., 2013, Proteze v hospodářských přiručkách 16. století, „Listy filologické” 136, s. 343-363.

Šlosar D., Večerka R., Dvořák J., Malčík P., 2009, Spisovný jazyk v dějinách české společnosti, Brno. [3., oprav. a dopl. vyd.] 
Utěšený S., 1955, Poznámky k dnešní situaci české historické dialektologie, „Slovo a slovesnost" 16, s. 146-153.

Válka J., 1968, Problém baroka jako kulturní a historické epochy, in: O barokni kultuře, Brno, s. 11-23.

Vintr J., 1992, Jazyk české barokni bible Svatováclavské, „Wiener Slavistisches Jahrbuch” 38, s. $197-212$.

Voit P., 2006, Daniel Adam z Veleslavina, in: Encyklopedie knihy: starši knihtisk a př́buzné obory mezi polovinou 15. a počátkem 19. století, Praha, online: $<$ https://www.encyklopedieknihy.cz/ >.

Weingart M., 1918, Vývoj českého jazyka, Praha.

\title{
MARTA ŠIMEČKOVÁ
}

\section{The (dis)continuity of the Czech language of the $16^{\text {th }}$ to the $18^{\text {th }}$ centuries (using the example of phonological changes)}

\begin{abstract}
A majority of the earlier scholarly publications (literary and linguistic) contain negative assessments of the Czech language from the $17^{\text {th }}$ and $18^{\text {th }}$ centuries. This valuation is in accordance with the political, social, religious and cultural developments in Bohemia after the battle of White Mountain (Bílá hora) on 8 November 1620. Following the battle, the Habsburg Monarchy was established and Bohemia was yet again subjected to the Catholic Church. The function of the Czech language was limited with German becoming the main language spoken by the Bohemian aristocracy and city dwellers. German was the official language and, along with Latin, the language of science. As a result of the functional restrictions, Czech books were printed in limited literary fields, especially religious, historical and practically-oriented texts. The language in which they were written was described as degraded, unstable and incorrect. It was connected with the decline of the standard language, deformed by dialectisms, neologisms and an enormous number of loan words from German. However, is this interpretation of the Czech language from the $17^{\text {th }}$ and $18^{\text {th }}$ centuries correct?

I have analysed over 100 prints from the $16^{\text {th }}$ to the $18^{\text {th }}$ centuries, focusing on four phonological phenomena: prothetic $v$-, dipthongisation $\dot{u}^{-}>o u$ - and $\dot{y}(\hat{l})>e j$ and the change $\dot{e}>\hat{i}$. These changes occurred in texts from the $16^{\text {th }}$ century (or even earlier), then some of them were repressed (ej, $i$ in word ending, prothetic $v$-) or fixed as a part of Czech print (initial ou-, $v$-by words stabilized with this nonetymological consonant). It is evident that 1 ) there was continuous development instead of discontinuity, 2) the earlier negative estimation of the Czech language after 1620 was inaccurate.

It is imperative to investigate the Czech language from a historical perspective in detail, without prejudice or ideology.
\end{abstract}

Keywords: phonology, Old Czech, dipthongisation, prothetic v-, prints, language change, historical linguistics. 